\title{
Aktivitas Pemberian Kredit Pada Bank Nagari Cabang Painan
}

\author{
Roza Islami Putri, Ratna Widayati \\ Akademi Keuangan dan Perbankan "Pembangunan" Padang \\ rozaislamiputri123@gmail.com
}

\begin{abstract}
The purpose of this study was to find out how to provide credit at Bank Nagari Cabang Painan. The research method of data collection uses two methods, namely library research and field research. The results of this study are the implementation of lending at Bank Nagari Cabang Painan in accordance with established procedures, starting from credit applications, credit analysis, recommendations, credit decisions, signing credit contracts, credit realization and credit supervision. The development of credit at the Bank Nagari Cabang Painan has increased every year this is due to the excellent financial performance of the Bank Nagari Cabang Painan.
\end{abstract}

Keywords: Credit Grant, Credit Progress

\section{PENDAHULUAN}

Menurut pasal 1 (2) Undang-Undang Nomor 10 Tahun 1998 tentang Perbankan, Bank adalah badan usaha yang menghimpun dana dari masyarakat dalam bentuk simpanan dan menyalurkannya kepada masyarakat dalam bentuk kredit atau bentuk lain dalam rangka meningkatkan taraf hidup masyarakat luas.(Ayu Rahma Gusti, 2020)

Bank pada hakikatnya selaku badankeuangan yang mempunyai fungsi sebagai financial intermediary yaitu perantara jarak dua belah pihak yang kelebihan dana (surplus) dan kekurangan dana (deficit), dengan cara menghimpun dana dari masyarakat dalam bentuk simpanan dan menyalurkannya kepada masyarakat dalam bentuk kredit.

Menurut pasal 1 (11) Undang-Undang Republik Indonesia No. 10 Tahun 1998 tentang Perbankan, Kredit adalah penyedian uang atau tagihan yang dapat dipersamakan dengan itu, berdasarkan perjanjian antara dua belah pihak yang mewajibkan peminjam untuk melunasi hutangnya setelah jangka waktu tertentu disertai dengan bunga.

Menurut (Alanshari \& Marlius, n.d.)Kredit adalah sesuatu yang dibutuhkan masyarakat mendorong dan memperlancar kegiatan perdagangan, baik di bidang menghasilkan barang dan jasa juga untuk meningkatkan atau memenuhi kebutuhan konsumsi masyarakat.

Alasan penelitian ini adalah untuk mengetahui bagaimana aktivitas pemberian kredit pada Bank Nagari Cabang Painan. Fasilitas pemberian kredit yang diberikan bank merupakan aset terbesar dari bank.Oleh karena itu pengawasan dalam pemberian kredit harus dilakukan sesuai prosedur dengan 
kebijakan-kebijakan yang telah ditetapkan dan pemberian kredit harus dilakukan dengan prinsip kehati-hatian agar kredit yang diberikan sesuai sasaran.

Dalam pemberian kredit, bank akan menghadapi berbagai situasi seperti jika debitur tidak membayar kewajibannya tepat pada waktunya, debitur menghilang dan sebagainya. Oleh karena itu, perlu dilakukan pengawasan terhadap pemberian kredit.

Bank Nagari Cabang Painan merupakan salah satu lembaga keuangan yang memberikan fasilitas kredit kepada masyarakat.Masyarakat dapat memanfaatkan fasilitas layanan ini untuk meminjam uang yang nantinya dapat digunakan sesuai dengan tujuan awal peminjaman.

Berdasarkan rincian diatas, penulis tertarik untuk membahasnya dalam Tugas Akhir mengambil judul mengenai “Aktivitas Pemberian Kredit Pada Bank Nagari Cabang Painan".

\section{Metode Penelitian}

\section{Metode Pengumpulan Data}

Untuk keperluan penelitian ini, pengumpulan data dilakukan dengan dua cara yaitu :

a. Riset Kepustakaan (Library Research)

Yaitu melakukan pengumpulan data melalui cara mempelajari teori-teori literatur, karya ilmiah, buku-buku, dan tulisan-tulisan yang ada hubungannya dengan objek penelitian.

b. Riset Lapangan (Field Research)

Yaitu penelitian yang langsung ke lapangan pada PT. Bank Nagari Cabang Painan untuk memperoleh data yang diperlukan dan melakukan wawancara untuk mendapatkan data primer.

\section{Metode Analisa Data}

Dalam menganalisis data, penulis menggunakan metode analisa data kualitatif.Metode analisa data kualitatif digunakan untuk metode penelitian yang menjelaskan secara deskriptif mengenai aktivitas pemberian kredit pada PT. Bank Nagari Cabang Painan.

\section{HASIL DAN PEMBAHASAN \\ Landasan Teori \\ Pengertian Bank}

Secara sederhana bank dapat didefinisikan sebagai lembaga keuangan yang kegiatan usahanya menghimpun dana dari masyarakat dan menyalurkan kembali dana tersebut kepada masyarakat serta menyediakan jasa perbankan lainnya.(Kasmir, 2011)

(Adinegoro, 1985), berpendapat bahwa "bank adalah usaha atau badan yang mempunyai pekerjaan memberikan pinjaman, menerima kredit berupa simpanan (deposito) selain pengiriman uang dan sebagainya”.

Bank merupakan badan usaha yang bertujuan untuk memenuhi kebutuhan kredit, baik dengan alat pembayaran sendiri maupun dengan uang yang diperoleh dari orang lain, atau dengan mengedarkan alat tukar baru berupa giro.(Dkk, 1997) 


\section{Pengertian Kredit}

Menurut (Suyatno, 1995)kredit adalah hak untuk menerima pembayaran atau keawajiban untuk melakukan pembayaran pada saat diminta atau dimasa mendatang , karena penyerahan barang saat ini. Menurut (Amelia \& Marlius, n.d.)Kredit adalah penyedian uang atau tagihan yang harus dilunasi beserta bunganya oleh peminjam sesuai dengan kesepakatan yang disepakati.

\section{Jenis-Jenis Kredit}

Menurut (Kasmir, 2003) jenis-jenis kredit dibagi dalam beberapa kelompok :

a. Dilihat dari segi kegunaannya

1) Kredit Investasi

Merupakan pinjaman yang digunakan untuk perluasan usaha atau membangun proyek guna keperluan rehabilitas, seperti kredit guna membangun pabrik dan membeli mesin-mesin.

2) Kredit Modal Kerja

Adalah kredit yang digunakan sebagai modal usaha.Biasanya kredit jenis ini berjangka pendek. Misalnya untuk membeli bahan baku, membayar gaji pengawai, dan modal kerja lainnya.

b. Dilihat dari segi tujuan kreditnya

1) Kredit Produktif

Yaitu kredit yang digunakan untuk meningkatkan usaha, produksi maupun investasi dimana kredit ini diberikan untuk menghasilkan barang dan jasa. Misalnya kredit untuk membangun pabrik yang akan menghasilkan barang, kredit pertanian dan kredit pertambangan yang menghasilkan bahan tambang.

2) Kredit Konsumtif

Merupakan kredit yang digunakan untuk keperluan pribadi, dalam kredit ini tidak ada tambahan barang dan jasa yang diproduksi, karena telah digunakan oleh perorangan dan badan usaha.Misalnya kredit mobil pribadi atau kredit perumahan.

3) Kredit Perdagangan

Kredit yang diberikan pada perdagang untuk memperlancar atau memperluas kegiatan perdagangannya.Seperti untuk membeli barang dagangnya yang diberikan pada agen.

c. Kredit dilihat dari segi jangka waktunya

1) Kredit Jangka Pendek

Yaitu kredit yang memiliki jangka waktu kurang dari satu tahun atau maksimal satu tahun dan biasanya di gunakan untuk modal kerja, misalnya untuk pertanian.

2) Kredit Jangka Menengah

Yaitu kredit dengan jangka waktu mulai dari satu tahun sampai tiga tahun. Kredit ini biasanya berbentuk kredit modal kerja atau kredit investasi yang jumlahnya relatif kecil.

3) Kredit Jangka Panjang

Yaitu kredit dengan jangka waktu pembayaran terlama. Jangka waktu 
pengembalian kredit ini selama ttiga tahun atau lima tahun. Kredit ini digunakan untuk pinjaman investasi jangka panjang seperti pembeloan mesin-mesin berat.

d. Dilihat dari segi jaminannya

1) Kredit dengan Jaminan

Adalah kredit yang diberikan jaminan, yang jaminannya dapat berupa barang berwujud maupun tidak berwujud. Artinya setiap kredit yang diberikan akan di lindungi oleh besarnya jaminan yang diberikan oleh calon debitur.

2) Kredit tanpa Jaminan

Yaitu kredit yang di berikan tanpa jaminan barang, jenis kredit ini diberikan dengan melihat prospek usaha, karakter dan loyalitas atau nama baik calon debitur saat berhubungan dengan bank atau pihak lain.

e. Kredit dilihat dari sektor usahanya

1) Kredit Pertanian, yaitu kredit yang di biayai untuk sektor perkebunan dan pertanian rakyat. Sektor pertama pertanian berupa kredit jangka panjang dan jangka pendek.

2) Kredit Perternakan, adalah kredit yang diberikan kepada sektor perternakan baik jangka panjang maupun jangka pendek. Misalnya kredit jangka pendek seperti perternakan ayam, dan kredit jangka panjang misalnya perternakan sapi dan kambing.

3) Kredit Perumahan, adalah kredit yang diberikan untuk membiayai perbaikan rumah, membeli atau membangun rumah.

4) Kredit Pendidikan, yaitu kredit yang diberikan untuk membangun sarana dan prasarana pendidikan atau bisa juga dalam bentuk kredit untuk peserta didik.

5) Kredit Pertambangan, adalah kredit yang membiayai jenis usaha pertambangan yang biasanya berjangka panjang. Misalnya tambang emas dan minyak bumi.

6) Kredit Profesi, adalah kredit yang diberikan kepada para profesional seperti dosen, dokter dan pengacara.

7) Kredit industri, yaitu kredit yang diberikan untuk membiayai industri, baik industri kecil, industri menengah,maupun industri besar.

\section{Tujuan Kredit}

Kredit memiliki beberapa tujuan yang berguna baik bagi kreditur (bank) dan debitur (nasabah), menurut (Maiwati \& Widayati, 2019)tujuan-tujuan kredit antara lain :

1) Mendapatkan Keuntungan

Bentuk bunga yang diterima bank sebagai balas jasa dan biaya administrasi perkreditanyang dibebankan kepada nasabah menjadi prioritas bagi sektor keuntungan yang menjadi prioritas bagi bank untuk mendapatkan laba yang sebesar-besarnya. Keuntungan dari bunga ini merupakan dana yang digunakan untuk kelangsungan operasional kegiatan usaha bank. Jika bank mengalami kerugian terus-menerus, tidak menutup kemungkinan bank akanmengalami likuiditas. 
2) Membantu Usaha Nasabah

Maksudnya kredit yang diberikan oleh kreditur kepada debitur, baik dalam bentuk dana investasi ataupun modal kerja, sesungguhnya dapat membantu usaha nasabah sehingga nasabah dapat mengembangkan usahanya itu serta memperluas usahanya.

3) Membantu Pemerintah

Dengan adanya kredit dari kreditur (bank) dapat membantu pemerintah dalam melaksanakan program pembangunan. Karena dengan adanya kredit dari bank, perkembangan baik Usaha Mikro Kecil dan Menengah (UMKM) maupun sektor Usaha Kredit Menengah (UKM) dapat mengembangkan dan memperluas usahnya sehingga dari langkah ini akan tercipta perputaran arus barang maupun jasa yang dapat memenuhi kehidupan hidup masyarakat luas.

\section{Fungsi Kredit}

Menurut (Muchdarsyah, 2000)fungsi kredit sebagai berikut :

a. Kredit dapat meningkatkan daya guna (utility) dari uang.

b. Kredit juga dapat meningkatkan peredaran serta lalu lintas uang.

c. Kredit merupakan salah satu alat stabilitas ekonomi.

d. Kredit menimbulkan kegairahan berusaha bagi masyarakat.

e. Kredit yaitu jembatan untuk meningkatkan pendapatan nasional.

f. Kredit juga sebagai alat hubungan ekonomi internasional.

g. Untuk meningkatkan daya guna barang.

\section{Prinsip-Prinsip Pemberian Kredit}

Ada beberapa hal yang perlu diperhatikan dalam menganalisa kredit yaitu nasabah harus memenuhi prinsip 5C, 7P, dan 3R. Penilaian kredit dengan prinsip 5C menurut (Dendawijaya, 2008) sebagai berikut :

a. Character

Yaitu suatu kenyakinan bahwa sikap ataupun watak dari orang-orang yangdiberikan kredit benar-benar dapat dipercayai, hal ini tercermin dari latar belakang debitur baik yang bersifat latar belakang pekerjaan maupun bersifat pribadi seperti cara hidup, gaya hidup, keadaan keluarga, dan social standingnya.

b. Capital

Yaitu untuk melihat apakah penggunaan modal sudah efektif, dilihat dari laporan keuangan (neraca dan laporan laba rugi) dengan melakukan pengukuran. Capital juga harus dilihat dari sumber mana saja modal yang ada sekarang ini.

c. Capacity

Adalah melihat nasabah dalam kemampuannya di bidang usaha yang berkaitan dengan pendidikannya, kemampuan berbisnis juga diukur dari kemampuannya memahami peraturan pemerintah.

d. Collacteral

Yaitu jaminan yang diberikan oleh calon nasabah baik yang bersifat fisik maupun non fisik. Jaminan harus melebihi jumlah kredit yang diberikan, 
keabsahan jaminan juga harus diperiksa sehingga jika terjadi kesalahan, maka jaminan yang dititipkan akan dapat kita gunakan secepat mungkin.

e. Condition of Economy

Yaitu kredit yang dinilai berdasarkan kondisi ekonomi dan politik saat ini dan yang akan datang menurut sektor masing-masing, dan prospek usaha dari debitur. Kemudian penilaian prospek sektor usaha yang dibiayai harus benar-benar memiliki prospek yang bagus. berikut :

Penilaian berdasarkan prinsip 7P menurut(Puspitaningtyas, 2012) sebagai

a. Personality (Kepribadian)

Yaitu penilaian nasabah ditinjau dari kepribadian nasabah dan perilaku mereka sehari-hari dan masa lalu. Personality ini juga mencakup sikap, emosi, tingkah laku, dan tindakan nasabah dalam menghadpi masalah.

b. Party

Adalah mengklasifikasikan nasabah ke dalam klasifikasi tertentu berdasarkan modal dan loyalitas serta karakter mereka. Hal tersebut dilakukan untuk membedakan fasilitas yang akan didapatkan.

c. Purpose

Yaitu mengetahui tujuan nasabah dalam mengambil kredit, termasuk jenis kredit yang diinginkan nasabah. Tujuan pengambilan kredit bermacammacam, seperti pinjaman modal kerja konsumtif dan lain sebagainya.

d. Prospect

Merupakan penilaian terhadap usaha nasabah di masa depan yang menguntungkan atau tidak, dengan kata lain memiliki prospek atau sebaliknya. Hal ini penting untuk diingat jika fasilitas kredit dibiayai tanpa prospek tidak hanya bank yang rugi tetapi juga nasabah.

e. Payment (pembayaran)

Adalah ukuran bagaimana nasabah mengembalikan kredit yang telah diambil dari sumber dana mana saja untuk pengembalian kredit.

f. Profitability (keuntungan)

Yaitu menganalisis bagaimana kemampuan nasabah dalam mencari keuntungan. Profitability diukur dari periode ke periode apakah akan tetap sama atau akan meningkat terutama dengan tambahan kredit yang didapat.

g. Protection (perlindungan)

Adalah tujuannya untuk bagaimana mempertahankan bisnis dan jaminan untuk mendapatkan perlindungan. Perlindungan ini bisa dalam bentuk jaminan barang atau jaminan asuransi.

Penilaian lain dengan menggunakan prinsip 3R menurut (Puspitaningtyas, 2012) antara lain :

a. Returns (Hasil Yang Diperoleh)

Yaitu pendapatan atau hasil yang diperoleh debitur setelah diberi kredit oleh bank cukup untuk mengcoverkredit beserta bunga, dan biaya lainnya.

b. Repayment (Pembayaran Kembali)

Yaitu kewajiban pembayaran kembali debitur kepada bank yang timbul akibat pemberian kredit harus disesuaikan dengan kemampuan debitur 
untuk membayar.

c. Risk Bearing Ability (Kemampuan Menyerap Risiko)

Yaitu bank harus mempertimbangkan kemampuan debitur untuk menyerap risiko jika terdapat hal-hal yang tidak terduga.Oleh sebab itu, perlu dipertimbangkan mengenai jaminan dan asuransi barang atau kredit cukup aman untuk menutupi risiko tersebut atau tidak.

\section{Aspek-Aspek Kelayakan Kredit}

Aspek-aspek penilaian dalam pemberian kredit (Tumbel, Yosia, 2015) sebagai berikut :

a. Aspek hukum/yuridis

Yaitu penilaian masalah legalitas badan usaha dan izin dimiliki oleh perusahaan yang mengajukan kredit.Penilaian dimulai dari pemeriksaan validitas dokumen dan penyelesaian akte perusahaan, sehingga dapat diketahui siapa pemilik perusahaan. Kemudian juga diperiksa keabsahan dokumen atau surat penting lainnya.

b. Aspek pasar dan pemasaran

Yaitu penilaian besar kecilnya permintaan terhadap produk yang dihasilkan sekarang dan di masa depan.

c. Aspek keuangan

Yaitu penilaian terhadap sumber dana yang dimiliki untuk membiayai bisnis mereka dan bagaimana menggunakan dana tersebut.

d. Aspek teknis/operasi

Yaitu untuk membahas masalah yang berkaitan dengan produksi, lokasi, dan lay out, seperti kapasitas mesin yang digunakan.

e. Aspek manajemen

Yaitu digunakan untuk menilai struktur organisasi perusahaan, sumber daya manusia, dan latar belakang pendidikan serta pengalaman sumber daya manusia.

f. Aspek sosial/ekonomi

Yaitu penilaian yang digunakan untuk menganalisis dampak yang disebabkan oleh adanya proyek terhadap perekonomian masyarakat secara umum.

g. Aspek analisi mengenai dampak lingkungan (AMDAL)

Yaitu analisis ini dilakukan secara mendalam sebelum kredit disalurkan, sehingga prokyek yang dibiayai tidak mengalami pencemaran lingkungan sekitarnya.

\section{Komite Kredit}

Komite kredit merupakan komite operasional yang membantu dewan direksi dalam mengevaluasi dan memutuskan permohonan kredit untuk jumlah dan jenis kredit yang ditetapkan oleh direksi.(Setyawan, 2017)

Menurut (Setyawan, 2017) tugas komite kredit yaitu :

a. Memberikan pelayananan hal-hal yang berkaitan dengan kredit yang disalurkan.

b. Meneliti dan menilai permohonan kredit baru yang jumlahnya besar.

c. Meneliti dan menilai permohonan mengenai perpanjangan kredit dan alasan atas permintaan tersebut.

d. Meneliti dan menilai semua kredit yang mengalami kemacetan untuk 
mengetahui sebabnya.

e. Meneliti apakah semua pemberian kredit telah sesuai dengan kebijakan perkreditan bank yang bersangkutan.

Adapun fungsi dari komite kredit menurut (Yuliana, Eka \& Widianti, 2014) yaitu :

a. Mengkoordinir serta mengecek atas kredit yang disalurkan

b. Melakukan analisis, dan menentukan keputusan pemberian fasilitas kredit.

\section{Prosedur Pemberian Kredit}

Prosedur pemberian kredit dan penilaian kredit oleh dunia perbankan secara umum antar bank yang satu dengan yang lain tidak jauh berbeda. Prosedur pemberian kredit dibedakan antara pinjaman perseorangan dan badan hukum, yang secara umum dapat dijelaskan sebagai berikut :

a. Permohonan kredit

Yaitu calon nasabah mengajukan permohonan kredit dengan persyaratan yang ditentukan oleh pihak bank, dan mengisi formulir yang telah disediakan.

b. Wawancara I

Yaitu penyelidikan kepada calon nasabah dengan langsung berhadapan dengan calon nasabah.

c. On the spot

Adalah kegiatan pemeriksaan ke lapangan dengan meninjau berbagai objek yang akan dijadikan usaha atau jaminan. Kemudian hasinya dicocokan dengan hasil wawancara 1.

d. Wawancara II

Adalah kegiatan perbaikan berkas, jika mungkin ada kekurangan pada saat on the spot dilapangan.

e. Keputusan kredit

Dalam hal ini menentukan apakah kredit yang akan diberikan atau ditolak, jika diterima, maka dipersiapkan administrasinya.

f. Penandatanganan akad kredit

Yaitu kelanjutan dari diputuskannya kredit, maka sebelum kredit dicairkan maka terlebih dahulu calon nasabah menandatangani akad kredit.

g. Realisasi kredit

Diberikan setelah penandatanganan surat-surat yang diperlukan dengan membuka rekening giro atau tabungan di bank yang bersangkutan.

h. Pencairan kredit

Pencairan atau pengambilan uang dari rekening sebagai realisasi dari pemberian kredit dan dapat diambil sesuai ketentuan dan tujuan kredit.

\section{Pembahasan}

\section{Pelaksanaan Pemberian Kredit}

Aktivitas pemberian kredit pada Bank Nagari Cabang Painan, dilaksankan sesuai dengan prosedur pemberian kredit yang merupakan proses secara bertahap serta berhati-hati agar kredit yang disalurkan dapat berjalan dengan lancar dan dikembalikan tepat waktu.

Berikut adalah proses pemberian kredit pada Bank Nagari Cabang Painan :

\section{a. Permohonan Kredit dari Calon Nasabah}


Permohonan ini diajukan oleh calon nasabah secara tertulis dengan cara mengisi formulir yang dilengkapi dengan syarat-syarat sebagai berikut :

1) Fotocopy identitas diri (KTP, SIM atau Pasport)

2) Pas photo $3 \times 4$ sebanyak 3 lembar

3) Fotocopy kartu keluarga (KK)

4) Fotocopy perizinan usaha (NPWP, SIUP, TDP, SITU)

5) Fotocopy dokumen jaminan (sertifikat tanah, BPKB, Surat Toko, dan lainnya)

6) Fotocopy buku nikah (bagi yang sudah menikah)

7) Fotocopy buku tabungan beberapa bulan terakhir

Setelah ituakan dilakukan pemeriksaan atau mengevaluasi kelengkapan dokumen debitur yang telah diajukan, tujuannya untuk mengetahui apakah dokumen yang diajukan sudah lengkap dan sesuai dengan persyaratan.

\section{b. Analisis Kredit}

Pihak Bank Nagari Cabang Painanmelanjutkan proses pemberian kredit dengan melakukan analisis cek agunan atau usaha debitur dengan menerapkan prinsip 5C untuk memenuhi syarat pemberian kredit, dengan cara menekankan kelayakan pemberian KUR sesuai prosedur. Untuk itu nasabah perlu memenuhi prinsip $5 \mathrm{C}$ sebagai berikut :

1) Character (Kepribadian)

Bank Nagari Cabang Painan melihat dan mengetahui bagaimana sifat dan tingkah laku dari calon nasabah pada kehidupan pribadinya maupun lingkungan usaha yang sedang dijalaninnya. Penilaian ini dilakukan dengan melakukan wawancara langsung terhadap calon nasabah pada saat mengajukan permohonan kredit.

2) Capital (Modal)

Penilaian atas modal ini dilihat dari laporan keuangan perusahaan debitur, posisi suatu perusahaan debitur berjalan dengan baik atau tidaknya.Dalam penilaian ini Bank Nagari Cabang Painan melakukan survey untuk mengetahui laporan keuangan perusahaan debitur.

3) Capacity (Kemampuan)

Penilaian ini diutamakan pada kemampuan calon debitur untuk dapat membayar angsuran yang telah ditetapkan, ini dilihat dari perusahaan atau pekerjaan debitur, apa perusahaannya berjalan dengan lancar dan gajinya sesuai dengan kredit yang dijalankan atau tidak.

4) Collateral (Jaminan)

Pada umumnya setiap aktivitas pemberian kredit diperlukan suatu agunan dari debitur berupa BPKB kendaraan bermotor/mobil, sertifikat rumah, sertifikat tanah dan lain-lain.Agunan digunakan sebagai sumber pembayaran kembali kredit jika debitur mengalami kesulitan dalam memenuhi kewajibannya dikemudian hari.

5) Condition of economic (Kondisi Ekonomi)

Penilaian terhadap usaha debitur, Bank Nagari Cabang Painan 
melihat bagaimana keadaan usaha debitur apakah aman atau tidak, dengan melihat dan meninjau keadaan usahanya dari beberapa tahun terakhir, sekarang dan masa yang akan datang. Agar mengurangi terjadinya kredit bermasalah atau kredit macet.

\section{c. Rekomendasi}

Merupakan usulan dan saran dari penjabat kredit atas suatu permohonan kredit kepada pimpinan Bank Nagari Cabang Painan dengan mempertimbangkan analisa kelayakan dan resiko atas permohonan nasabah untuk disetujui atau ditolak oleh pemimpin cabang.

\section{d. Keputusan Kredit}

Keputusan kredit biasanya diberikan dengan mempertimbangkan analisa kelayakan dan resiko. Pemberitahuan keputusan dilakukan secara tertulis dengan menggunakan surat pemberitahuan persetujuan kredit. Apabila keputusan kredit ditolak oleh bank maka akan di sampaikan melalui surat penolakan dari bank.

e. Penandatanganan Akad Kredit

Setelah permohonan kredit disetujui, maka kedua belah pihak melakukan perjanjian kredit dengan menanda tangani akad kredit diatas materai Rp 10.000, dan pihak bank akan mengikat agunan yang dijaminkan oleh pihak debitur.

\section{f. Realisasi Kredit}

Pada Bank Nagari Cabang Painan realisasi kredit dilakukan melalui rekening tabungan, jika nasabah belum memiliki rekening di Bank Nagari Cabang Painan maka nasabah wajib membuka buku tabungan baru atau membuat rekening baru.

\section{g. Pengawasan Kredit}

Demi kelancaran pengembalian kredit tersebut, petugas Bank Nagari Cabang Painan melakukan monitoring kepada nasabah secara berkala, sehingga setiap permasalahan yang akan timbul dapat segera diketahui dan dapat dicari jalan keluarnya.

\section{Perkembangan Kredit}

Perkembangan kredit Pada Bank Nagari Cabang Painan dapat dilihat pada tabel berikut ini :

\begin{tabular}{ccc} 
& \multicolumn{2}{c}{ Tabel 1 } \\
& $\begin{array}{c}\text { Perkembangan Kredit Bank Nagari } \\
\text { Cabang PainanPeriode 2018-2020 } \\
\text { ( Dalam Rupiah) }\end{array}$ & Plafond \\
\hline Tahun & Jumlah Nasabah & 971.395.801.700 \\
\hline 2018 & 6677 & 1.043 .863 .219 .729 \\
2019 & 6904 & 1.087 .907 .340 .452 \\
\hline 2020 & 8066 & \\
\hline
\end{tabular}

Sumber : PT.Bank Nagari Cabang Painan

Dari data di atas, terlihat jelas adanya peningkatan jumlah debitur disetiap tahunnya. Pada tahun 2018 kredit yang disalurkan sebesar Rp 971.395.801.700 
dengan jumlah debitur sebanyak 6677 pada tahun 2019 kredit yang disalurkannya naik menjadi Rp 1.043.863.219.729 dengan jumlah debitur 6904, dan pada tahun 2020 jumlah kredit yang diberikan meningkat lagi sebesar Rp 1.087.907.340.452 dengan jumlah debiturnya 8066.

Dapat disimpulkan bahwa perkembangan pemberian kredit mengalami peningkatan disetiap tahunnya hal ini disebabkan oleh kinerja keuangan Bank Nagari Cabang Painan yang sangat baik.

\section{SIMPULAN}

Aktivitas pemberian kredit pada Bank Nagari Cabang Painan sesuai dengan prosedur yang ditetapkan yaitu mulai dari permohonan kredit, analisis kredit, rekomendasi, keputusan kredit, penandatanganan akad kredit, realisasi kredit dan pengawasan kredit. Perkembangan pemberian kredit mengalami peningkatan disetiap tahunnya hal ini disebabkan oleh kinerja keuangan Bank Nagari Cabang Painan yang sangat baik.

\section{DAFTAR PUSTAKA}

Adinegoro, R. T. (1985). Perbankan Masalah Pemodalan Dana Potensial. Padya Paramitha, Jakarta.

Alanshari, F., \& Marlius, D. (2018). Prosedur Pemberian Kredit KPR Pada PT. Bank Tabungan Negara (Persero) TBK Cabang Pembantu Bukittinggi. https://doi.org/10.31227/osf.io/rsfhc.

Amelia, L., \& Marlius, D. (2018). Pengendalian Kredit Dalam Upaya Menciptakan Bank Yang Sehat Pada PT. Bank Pembangunan Daerah Sumatera Barat Cabang Utama Padang. https://doi.org/10.31227/osf.io/kpc64.

Asyari, A., \& Marlius, D. (2021). Proses Penyelesaian Kredit Bermasalah Pada PT. BPD Sumatera Barat Cabang Pasar Raya Padang. https://doi.org/10.31219/osf.io/3hfcr

Ayu Rahma Gusti, W. R. (2020). Upaya Penyelesaian Kredit Bermasalah Pada Bank Nagari Cabang Pembantu Tarusan. 1(11), 1-13.

Dendawijaya, L. (2008). Manajemen Perbankan. Gramedia Indonesia.

Dkk, T. S. (1997). Kelembagaan. Gramedia.

Kasmir. (2003). Bank dan Lembaga Keuangan Lainnya. PT Raja Grafindo Persada.

Kasmir. (2011). Implementasi Prinsip Kehati-hatian Dalam Pemberian Kredit Usaha Rakyat Pada PT. Bank Rakyat Indonesia (PERSERO) Tbk. CABANG PONOROGO.

Maiwati, S., \& Widayati, R. (2019). Aktivitas Pemberian Kredit Komersial Pada Bank Nagari Cabang Sijunjung. 1-12.

Muchdarsyah, S. (2000). "Dasar-Dasar dan Teknik Manajemen Kredit.” Bina aksara.

Puspitaningtyas, A. (2012). Analisis Prinsip 5C Dan 7P Pada Penyaluran Kredit Di PT. BPR Antar Rumeksa Arta Karanganyar.

Setyawan, A. (2017). Analisis Prosedur Pemberian Kredit Pada PT. Bank Perkreditan Rakyat Artha Samudera Indonesia Kediri. 01(08). 
Suyatno, T. (1995). Dasar-Dasar Perkreditan Edisi Empat. PT Gramedia Pustama Utama.

Tumbel, Yosia, C. (2015). Aspek-Aspek Penilaian Dalam Pemberian Kredit Bank. III (3), 44-51.

Yuliana, Eka, W., \& Widianti, H. (2014). Sistem Pemberian Kredit Pada Unit Simpan Pinjam KUD Karya Mina Kota Tegal. 09. 